\section{When democracy fails}

Most members of voluntary organizations concerned with protecting and conserving wildlife and the natural environment prefer not to take part in direct action. Like the great majority of humanity, in the course of our everyday lives we prefer to avoid any activity that might expose us to the public gaze, to ridicule, or even hostility. We are concerned, of course, about conservation issues, but see our contribution as being financial, from our membership subscriptions, and supportive, in lending weight to the numbers our organization can claim to represent. If an issue arouses us particularly deeply, we might write letters of protest or collect signatures for a petition. Under ordinary circumstances relatively few would venture further than that, believing that the democratic process will give us, ultimately, the results we want. Following democratic procedures may well be the best way to do things, but the process can be frustratingly slow. More seriously for conservation concerns, the results may come too late to save species and habitat. What can be done then?

The residents of the Charlotte Islands off the British Columbian coast of Canada are facing this question now. South Moresby, the wildest part of the island group, has been the focus of a campaign to make it a national park for 12 years. Its ancient Sitka spruce, western hemlock and red cedars are among the largest trees on earth. Its fauna includes the world's largest population of rare Peale's peregrine falcons and Canada's largest nesting concentration of bald eagles. The Government had promised that there would be no more logging in the area until a final decision had been made on land use. But on 18 October 1985 British Columbia's Environment Minister broke that promise, saying that logging would be allowed on Lyell Island, South Moresby, while a special committee, whose appointment was announced at the same time, was given three months to examine land-use conflicts in 16 areas in the State for which wilderness protection had been suggested and to review the boundaries of eight parks. Although timber and mining interests are represented on the committee, environmentalists are not. A spokesman for the Islands Protection Society said that the Society had never before taken a confrontational position, having worked within the confines of the system for 12 years, but the group's 1000 members were so angry that they would now take action, since democracy did not seem to be working.

When an issue becomes as urgent as this, people are more likely to overcome their reticence about acting in defence of the environment. We have yet to hear what kind of action will be taken in the Canadian case. One is reminded of the village women of India, hugging the trees to prevent the woodcutters felling them. One remembers people lying down in front of bulldozers in Tasmania and Queensland in Australia, to try to stop the destruction of the rain forest. And one remembers Greenpeace, whose activities so threatened the French Government that a vessel was sunk and a life lost. Confrontations are best avoided, but they may become necessary to save something precious when all other methods have failed. Confrontations, however, can be counterproductive, polarizing a situation, pushing groups towards extremes and hardening attitudes. We need people, in the end, to adopt a conservation ethic because of the way they feel, rather than because they have been forced into it.

Non-violent protests are one thing; the conservation movement needs individuals willing to make a nuisance of themselves. It is much more open to question whether the conservation movement needs the publicity currently being attracted by the activities of a radical environmental group called Earth First! (the '?' is an integral part of the name). Its tactics sometimes involve the destruction of property, in sabotaging developmental projects, and have led to the arrests of some sympathizers, whose numbers are currently estimated to be about 10,000. The group wants to see large areas of America returned to wilderness, including the closing of more than one million acres north-west of Los Angeles to human use to save the Californian condor.

Most conservationists understandably wish to dissociate themselves from these illegal and sometimes violent tactics. At the same time we should not forget that they are provoked by a kind of violence that largely goes unrecognized as such-the violence of our institutions against other species. 